\title{
Evaluation and Selection of Fine and Semi Fine Rice Grain (Oryza sativa L.) Genotypes for Agro-Morphological Traits under Augmented Block Design in Temperate Conditions of Kashmir Valley
}

\author{
Uzma Mehraj", F.A. Sheikh $^{1}$, S. Najeeb ${ }^{2}$, Mushtaq Ahmad ${ }^{3}$,A.B. Shikari ${ }^{2}$, \\ Shabir H. Wani' ${ }^{2}$ M.A. Ahangar', M.A. Khan' ${ }^{1}$ and M.A. Bhat ${ }^{1}$ \\ ${ }^{1}$ Faculty of Agriculture, Wadura Sopore, India \\ ${ }^{2}$ Mountain Research Centre for Field Crops, Khudwani, Anantnag, \\ Jammu \& Kashmir-192102, India \\ ${ }^{3}$ Mountain Agriculture Research and Extension Station, Kargil, SKUAST-K, India \\ *Corresponding author
}

\section{Keywords}

Temperate,

Augmented block design, Fine and

semi-fine rice,

ANOVA

Article Info

Accepted:

12 October 2019

Available Online:

10 November 2019

\section{A B S T R A C T}

Field experiment was conducted for evaluation and selection of fine and semi-fine grain rice genotypes under temperate conditions of Kashmir valley during Kharif 2017-18. In this experiment among 56 fine and semi fine rice grain genotypes evaluated under augmented block design, sufficient amount of variability was observed for grain yield per hectare and its components. The analysis of variance for grain yield and its attributing traits among treatments, checks and checks + checks vs varieties revealed presence of significant variation in the studied genotypes. However with respect to checks, non-significant differences were recorded for tillers plant ${ }^{-1}$, plant height $(\mathrm{cm})$ and test weight $(\mathrm{g})$. The results indicated that among 56 rice genotypes including checks, only 19 rice genotypes expressed higher yield and its attributing traits compared to four checks varieties under temperate conditions of Kashmir. The genotypes AVT-FG-V1(74.8 q/ha), AVT-FG-V2(69.1q/ha), AVT-FGV4(59.7 q/ha), AVT-FG-V5(70.7 q/ha), AVT-FG-V6(69.1 q/ha), AVT-FG-V8(66.9 q/ha), PVT-V1(61.5 q/ha), IURON-10(59.9 q/ha), IURON-8(49.1 q/ha), IURON-20 (43.7 q/ha), IRTON-23(48.7 q/ha), IRTON-25 (81.6 q/ha), AVT-1-V3(56.1 q/ha), IVT-BT-3010(41.9 q/ha), IVT-1M(H) 2817(55.7 q/ha), IVT-1E(H) 2606 (80.1 q/ha), AVT-1E(H) 2511(60.4 q/ha), IVT-1M(H) 2810 (40.8 q/ha), and AVT-1M(H) 2506 $(41.0 \mathrm{q} / \mathrm{ha})$ were the top ranking genotypes with respect to yield per hectare.

\section{Introduction}

Rice is food grain crop of global importance with special preference in Asian countries.
Rice belongs to the genus Oryza which consists of 23 wild and 5 main cultivated subspecies namely indica, aus, aromatic (basmati), temperate japonica, and tropical 
japonica. Indica sub-species originated from India and South China region; tropical japonica subspecies from Japan, Korea, and North China; temperate japonica from Java and Indonesia: aus from Bangladesh and India and aromatic (Basmati) from western Asia, South Asia and India Garris et al., (2005); Hughes et al.,(2008). The demand for grain basmati is emerging day by day and India (65\%) and Pakistan (35\%) are the global supplier of fine grain basmati types. In India, basmati rice cultivars are cultivated mainly in the foothills of the Himalayas, Haryana, Punjab and Uttar Pradesh, Himachal Pradesh, Jammu \& Kashmir and Delhi Shobha, et al.,(2006). Cultivation of basmati rice in India is done on an area of about 2.10 million ha resulting in production of 8.70 million tons with an export potential of 3.70 million tons (AIREA, 2015). India produces about $70 \%$ of the world's basmati production and nearly two third of the total production is exported to other countries, especially to the Gulf and European countries Verma et al., (2012). Fine grain basmati rice is praised for its unique quality and gives pleasant flavour after cooking. In India Basmati rice is characterized by extra long, superfine slender grains having a length to breadth ratio of more than 3.5 , sweet taste, soft texture, delicate curvature and an extra elongation with least breadth-wise swelling on cooking. The aromatic basmati and fine/semi grain rice variety offers high returns to farmers, enjoying a preferential treatment both in domestic and international markets generating three times higher income so farmers are more inclined to it. In Jammu \& Kashmir area under basmati rice is 68.45 thousand ha with a production of 240.77 thousand tons. Ranbir Singh Pura of district Jammu has the highest area under Basmati, i.e. 49,100 ha followed by Kathua, and Samba districts (BEDF, 2016). Kashmir valley has a tradition of growing short to medium bold seeded rather coarse grained rice varieties with low to intermediate amylose content. In the time of festivals and matrimonial occasions high demand for fine grained and aromatic rices is being observed in the market, as a result a huge quantity is being imported from neighbouring states for making special dishes like mutton pulavo (mutton and fried rice) and vegetable pulavo putting lot of pressure to state exchequer so the need of the hour is to breed for the varieties which are fine and semi-fine in nature with good grain quality. Keeping this in view, the present study was envisaged to assess the agro-morphological traits of 56 fine and semi fine rice grain genotypes under temperate conditions of Kashmir valley.

\section{Materials and Methods}

Fifty six genotypes of rice comprising of both fine and semi-fine rice (Oyzea sativa L.) germplasm including four check varieties were grown in an augmented block design at mountain research centre for field crops khudwani, Kashmir, India during Kharif 2017. The experimental site is situated at an altitude of $1560 \mathrm{~m}$ above mean sea level with a well-defined mandate of high yielding and early maturing rice varieties and represents temperate conditions.

Five rows of $7 \mathrm{~m}$ length for each entry were sown at a spacing of $20 \mathrm{~cm}$ among rows and $15 \mathrm{~cm}$ between plants. Crops were raised following recommended package of practices. The data was recorded on yield and its attributing components viz. Days to 50\% flowering, Number of productive tillers plant ${ }^{1}$, Plant height $(\mathrm{cm})$, Panicle length $(\mathrm{cm})$, Number of spikelets panicle ${ }^{1}$, Number of seeds panicle- ${ }^{-}$, Spikelet fertility (\%), Days to maturity and 1000-grain weight (g). The means were subjected to analysis as per augmented block design (Table 1). The genotypes which showed significant performance for yield and component traits upon the best checks were selected. 


\section{Results and Discussion}

The analysis of variance for grain yield and its attributing characters among treatments, checks and checks + checksvs varieties revealed presence of significant variation in the genotypes studied. However with respect to checks non-significant differences were recorded for productive tillers plant-1, Plant height $(\mathrm{cm})$ and 1000-grain weight $(\mathrm{g})$ (Table $1)$.

Earliness is always desirable, as the genotypes both fine and semi fine that matures early particularly under temperate conditions of Kashmir escape from lower day and night temperature particularly at grain filling stage which results in loose packing of starch material leading to grain chalkiness and low head rice recovery and poor grain quality. The examination of data on the days to $50 \%$ flowering revealed presence of good variation between the treatments. Maximum number of days were recorded in case of IIRON-5(119) followed by IIRON-34(113), GSR-30(111), IVT-BT-3020(110), IURON-21(110), GSR$35(109)$ while as minimum number of days were taken by IVT-IE(H)2604(88), AVTI(E)2511(89), IVT.IE(H)2816(89) followed by IVT.1E(H)2609(91), GSR-34(91), IVT.1(E)2506 (92), PVT-V1(93) and AVT-1V3(93) (Table 2).

Early maturing varieties like AVT.1E(H)2511, AVT.1(E) 2506, PVT-V1, AVT-1-V3 were identified as desirable types for temperate conditions of climate as well as for yield as the same was reported by (Akhter et al., 2015). In this study, the early maturing genotypes with high yield were IVT.1M(H)2817, IURON-20, IURON-8, IURON-10, IRTON-23 and IRTON-25. Also (Ndour et al., 2016; Ranaweke et al., 2014) found that early maturing genotypes were more adapted to temperate climatic conditions than late late maturing ones because low temperature affects the growth, development and yield of rice plant and constitute a major constraint to rice production.

Number of effective tillers produced by each plant constitutes an important agromorphological trait for grain yield in rice Tao et al., 2006 and Sadeghi (2011). In present study, significant differences were observed for number of productive tillers per plant among the rice genotypes. The highest number of productive tillers per plant were found in IRTON-23, IVT.IM(H)2801, IVT.IE(H)2604.

It varied from 9.2 (GS-394) to 24.0 (IRTON23). Also Shoba et al., 2006 reported that the number of tillers per plant contributed maximum direct effect on yield. Naseem et al., (2014) reported that the number of productive tillers per plant, number of spikelets per panicle, number of grains per panicle and days to maturity had positive direct effect on grain yield per plant.

Good amount of variability were present for plant height also. GS-393 and GS-407 (138 $\mathrm{cm})$, GS-394 (136cm), IVT.1M(H)-2816(132 $\mathrm{cm})$, IVT.1E(H)-2609 $(130 \mathrm{~cm})$ and GS-435 $(129 \mathrm{~cm})$ were tall, while IURON-20, IRTON23 and GSR-30 were too dwarf. $60 \%$ of the fine and semi fine rice genotypes recorded plant height in the range of $80 \mathrm{~cm}-120 \mathrm{~cm}$. In the present study high yield was associated with short to medium stature genotypes viz. AVT-FG-V1, AVT-FG-V2,AVT-FG-V4,AVTFG-V5,AVT-FG-V6,AVT-FG-V8, AVT-1-V3, IVT-BT-3010， PVT-V1， IVT.1M(H)-2817, IURON-20, IURON-8, IURON-10, IRTON23 and IRTON-25 (Table 2). Similar results were reported by Yadav et al., (2011). However it has been reported that plant height was affected by many factors like plant density, plantation method and fertilizer application reported by Aide and Beighly (2006), Ashrafuzzaman et al., (2009) and Uddin et al., (2010). 
In this study, most of the early maturing genotypes had longer panicles ranged from $20-27 \mathrm{~cm}$ in length with more number of grains per panicle which resulted in higher yield. Similar results were reported by Vijay Kumar (2015) and Thippeswamy et al., (2016). Sajid et al., (2015) concluded that panicle length alone does not determine the high grain yield as traits such as grain size, grain shape, higher number of tillers/plant, longer panicles and greater number of grains/panicle ultimately contribute to higher grain yield. Similarly, Wattoo et al., (2010) reported that the days to maturity had highest direct effect on grain yield per plant.

Number of spiklets per panicle was significantly influenced by the genotypes studied. Among these genotypes, the highest number of spiklets produced were AVT.1M(H)-2704 (324) followed byIVT-BT3010 (321), followed byIVT-BT-3020(321), GS-390 (286) and Pusa Basmati-1509 (79), a check variety produced the lowest number of spiklets per panicle. Number of spikelets per panicle provide useful information for the rice breeder and these characters have direct effect on yield per plant Sadeghi (2011), also spikelet per panicle have strong correlation with panicle length (Ranawake et al., 2013).

In this study the highest number of seeds per panicle were found in GS-390(205) followed by IURON-21 (187) and lowest number of grains were found in Pusa Basmati-1509 (57) and AVT-FG-V2 (57). However the high yielding genotypes had significant number of grains per panicle with an average mean of 125.5 coupled with higher number of panicles per plant and higher yield and maximum variability was observed grains per panicle. Among these components grain yield was significantly increased by the number of grains per panicle as reported Basenti et al., (2018). It is found that higher number of grains per panicle was found in genotypes which mature early probably due to the interaction of higher solar radiation associated with optimum temperature Manan et al., (2009). Roy et al., (2012) studied the variation in agro-morphological and grain quality traits among traditional and Basmati-type aromatic/quality rice and observed highest variation for grains per panicle followed by grain yield per plant.

Table.1 Augmented design analysis of variance for yield and its attributing characters

\begin{tabular}{|c|c|c|c|c|c|c|c|c|c|c|c|}
\hline \multirow[t]{2}{*}{ SOV } & \multirow[t]{2}{*}{ D.F } & \multicolumn{10}{|c|}{ Mean squares } \\
\hline & & $\begin{array}{c}50 \% \\
\text { flowering }\end{array}$ & $\begin{array}{l}\text { Tillers } \\
\text { plant-1 }\end{array}$ & $\begin{array}{l}\text { Plant } \\
\text { height } \\
(\mathrm{cm})\end{array}$ & $\begin{array}{c}\text { Panicle } \\
\text { length }(\mathrm{cm})\end{array}$ & $\begin{array}{l}\text { Spiklets } \\
\text { panicle-1 }\end{array}$ & $\begin{array}{c}\text { Seeds } \\
\text { Panicle }^{-1}\end{array}$ & $\begin{array}{c}\text { Spikelet } \\
\text { Fertility } \\
(\%)\end{array}$ & $\begin{array}{l}\text { Days to } \\
\text { maturity }\end{array}$ & $\begin{array}{l}\text { 1000-Grain } \\
\text { Weight }(\mathrm{g})\end{array}$ & $\begin{array}{l}\text { Yield } \\
\text { (q/ha) }\end{array}$ \\
\hline trt.adj & 55 & $\begin{array}{c}44.02 * \\
*\end{array}$ & $6.47 * *$ & $\begin{array}{c}328.8^{*} \\
*\end{array}$ & $5.63 * *$ & $2719 * *$ & $1302 * *$ & $\begin{array}{c}186.3^{*} \\
*\end{array}$ & $17.33 * *$ & $6.63 * *$ & $\begin{array}{c}492.0 \\
* *\end{array}$ \\
\hline Control & 3 & $\begin{array}{c}21.49 * \\
*\end{array}$ & 0.03 & 6.8 & $9.37 * *$ & $9018 * *$ & $10413 * *$ & $\begin{array}{c}552.5^{*} \\
*\end{array}$ & $26.67 * *$ & 11.14 & $\begin{array}{c}3483 . \\
7 * *\end{array}$ \\
\hline $\begin{array}{c}\text { Control + } \\
\text { control.VS. } \\
\text { aug }\end{array}$ & 52 & $\begin{array}{c}45.32 * \\
*\end{array}$ & $6.84 * *$ & $\begin{array}{c}347.4^{*} \\
*\end{array}$ & $5.41 * *$ & $2356^{* *}$ & $776^{* *}$ & $\begin{array}{c}165.2^{*} \\
*\end{array}$ & $16.79 * *$ & $6.37 * *$ & $\begin{array}{c}319.4 \\
* *\end{array}$ \\
\hline Residuals & 15 & 3.22 & 0.38 & 4.9 & 0.77 & 90 & 29 & 27.6 & 7.40 & 0.29 & 3.6 \\
\hline
\end{tabular}


Table.2 Adjusted mean of 56 genotypes including checks using augmented design in temperate conditions of Kashmir valley

\begin{tabular}{|c|c|c|c|c|c|c|c|c|c|c|}
\hline Genotypes & $\begin{array}{c}\text { Days to } \\
50 \% \\
\text { flowering }\end{array}$ & $\begin{array}{l}\text { Tillers } \\
\text { plant-1 }\end{array}$ & $\begin{array}{c}\text { Plant } \\
\text { height } \\
\text { (cm) }\end{array}$ & $\begin{array}{c}\text { Panicle } \\
\text { length } \\
(\mathrm{cm})\end{array}$ & \begin{tabular}{|c|} 
Spiklets \\
panicle-1
\end{tabular} & \begin{tabular}{|c|} 
Seeds \\
Panicle-1
\end{tabular} & $\begin{array}{c}\text { Spikelet } \\
\text { Fertility } \\
(\%)\end{array}$ & $\begin{array}{c}\text { Days to } \\
\text { maturity }\end{array}$ & $\begin{array}{l}\text { 1000- } \\
\text { Grain } \\
\text { Weight } \\
\text { (g) }\end{array}$ & $\begin{array}{l}\text { Yield } \\
\text { (q/ha) }\end{array}$ \\
\hline SKUA-494 & 104 & 13.8 & 92 & 25 & 128 & 106 & 84 & 138 & 24 & 69.7 \\
\hline AVT-FG-V8 & 101 & 12.3 & 92 & 26 & 148 & 108 & 74 & 136 & 26 & 66.9 \\
\hline GS-388 & 98 & 11.6 & 90 & 26 & 179 & 126 & 73 & 135 & 26 & 22.3 \\
\hline GS-389 & 98 & 10.5 & 81 & 25 & 174 & 128 & 76 & 135 & 25 & 22.3 \\
\hline GS-390 & 96 & 11.5 & 105 & 25 & 286 & 205 & 74 & 135 & 23 & 26.7 \\
\hline GS-393 & 98 & 11.3 & 138 & 25 & 202 & 159 & 79 & 139 & 26 & 23.0 \\
\hline GS-394 & 98 & 9.2 & 136 & 24 & 163 & 138 & 85 & 138 & 27 & 19.6 \\
\hline GS-407 & 96 & 11.4 & 138 & 26 & 154 & 117 & 76 & 138 & 29 & 22.9 \\
\hline GS-423 & 98 & 10.0 & 91 & 24 & 195 & 119 & 62 & 140 & 31 & 23.6 \\
\hline GS-435 & 97 & 13.2 & 129 & 25 & 194 & 143 & 74 & 137 & 25 & 21.4 \\
\hline IVT-BT-3027 & 98 & 13.0 & 91 & 27 & 151 & 114 & 75 & 136 & 27 & 26.1 \\
\hline SKUA-420 & 106 & 13.9 & 89 & 26 & 146 & 137 & 94 & 140 & 27 & 72.4 \\
\hline IVT-BT-3024 & 96 & 12.1 & 88 & 24 & 208 & 187 & 90 & 137 & 22 & 20.0 \\
\hline IVT-BT-3022 & 97 & 12.3 & 93 & 22 & 132 & 76 & 58 & 136 & 28 & 22.2 \\
\hline IVT-BT-3020 & 110 & 10.8 & 86 & 21 & 321 & 180 & 57 & 136 & 24 & 26.0 \\
\hline IVT-BT-3010 & 100 & 14.2 & 92 & 24 & 174 & 144 & 83 & 137 & 25 & 41.9 \\
\hline AVT-1-V3 & 93 & 13.0 & 97 & 25 & 223 & 165 & 75 & 142 & 27 & 56.1 \\
\hline AVT-I(E)2502 & 98 & 17.5 & 92 & 23 & 182 & 129 & 72 & 142 & 24 & 23.2 \\
\hline 2511 & 89 & 14.0 & 109 & 21 & 183 & 152 & 84 & 139 & 26 & 60.4 \\
\hline 2504 & 98 & 14.0 & 94 & 21 & 190 & 115 & 61 & 139 & 27 & 19.9 \\
\hline 2506 & 92 & 16.5 & 128 & 24 & 129 & 110 & 85 & 141 & 27 & 41.0 \\
\hline 2508 & 94 & 15.4 & 85 & 24 & 162 & 125 & 78 & 140 & 27 & 23.5 \\
\hline P-B-1509 & 108 & 13.9 & 90 & 28 & 79 & 57 & 72 & 143 & 27 & 28.0 \\
\hline 2514 & 94 & 15.2 & 91 & 20 & 195 & 132 & 68 & 138 & 33 & 18.9 \\
\hline IVT.IE(H)2604 & 88 & 19.4 & 113 & 24 & 178 & 136 & 77 & 142 & 26 & 26.0 \\
\hline 2606 & 100 & 14.6 & 108 & 21 & 183 & 134 & 73 & 141 & 27 & 80.1 \\
\hline 2609 & 91 & 15.7 & 130 & 23 & 185 & 138 & 75 & 143 & 22 & 32.4 \\
\hline 2617 & 94 & 17.3 & 118 & 22 & 147 & 119 & 81 & 140 & 27 & 17.7 \\
\hline AVT.IM(H)2704 & 98 & 16.8 & 80 & 21 & 107 & 72 & 68 & 141 & 24 & 15.1 \\
\hline 2712 & 98 & 14.5 & 95 & 22 & 324 & 105 & 32 & 140 & 22 & 19.6 \\
\hline IVT.IM(H)-2801 & 97 & 21.4 & 129 & 23 & 142 & 108 & 76 & 139 & 26 & 22.2 \\
\hline 2817 & 94 & 11.6 & 104 & 24 & 170 & 109 & 64 & 137 & 20 & 55.7 \\
\hline 2810 & 94 & 14.8 & 98 & 23 & 148 & 95 & 64 & 143 & 23 & 40.8 \\
\hline P-S-3 & 108 & 13.9 & 90 & 25 & 171 & 151 & 89 & 142 & 27 & 28.6 \\
\hline 2816 & 89 & 15.8 & 132 & 23 & 167 & 116 & 69 & 140 & 25 & 20.9 \\
\hline GSR-30 & 111 & 17.9 & 74 & 19 & 165 & 114 & 67 & 136 & 25 & 36.2 \\
\hline GSR-33 & 97 & 17.0 & 119 & 21 & 157 & 118 & 73 & 143 & 26 & 41.5 \\
\hline GSR-34 & 91 & 15.3 & 121 & 20 & 186 & 142 & 75 & 142 & 24 & 63.6 \\
\hline GSR-35 & 109 & 17.0 & 124 & 21 & 143 & 106 & 73 & 144 & 27 & 38.7 \\
\hline IURON-21 & 110 & 11.0 & 104 & 25 & 213 & 187 & 86 & 146 & 32 & 36.1 \\
\hline IURON-20 & 103 & 14.4 & 66 & 23 & 148 & 107 & 71 & 142 & 25 & 43.7 \\
\hline IURON-8 & 104 & 10.8 & 106 & 22 & 151 & 120 & 78 & 146 & 24 & 49.1 \\
\hline IURON-18 & 105 & 11.1 & 94 & 20 & 152 & 122 & 79 & 145 & 25 & 36.2 \\
\hline IURON-15 & 103 & 10.4 & 99 & 18 & 155 & 110 & 69 & 166 & 23 & 30.8 \\
\hline
\end{tabular}




\begin{tabular}{|c|c|c|c|c|c|c|c|c|c|c|}
\hline AVT-FG-V1 & 98 & 11.9 & 91 & 27 & 144 & 127 & 89 & 137 & 26 & 74.8 \\
\hline IURON-10 & 104 & 10.6 & 89 & 22 & 173 & 123 & 71 & 147 & 25 & 59.9 \\
\hline IRTON-23 & 99 & 24.0 & 67 & 22 & 175 & 123 & 69 & 143 & 20 & 48.7 \\
\hline IRTON-25 & 99 & 16.9 & 120 & 22 & 182 & 134 & 85 & 139 & 26 & 81.6 \\
\hline IIRON-5 & 119 & 11.8 & 73 & 19 & 242 & 122 & 48 & 140 & 33 & 21.6 \\
\hline IIRON-34 & 113 & 12.6 & 86 & 20 & 175 & 114 & 64 & 137 & 25 & 34.9 \\
\hline IIRON-35 & 109 & 12.8 & 96 & 20 & 178 & 134 & 75 & 138 & 27 & 36.5 \\
\hline PVT-V1 & 93 & 13.0 & 126 & 21 & 191 & 150 & 78 & 143 & 26 & 61.5 \\
\hline AVT-FG-V2 & 99 & 12.0 & 91 & 25 & 148 & 57 & 42 & 136 & 25 & 69.1 \\
\hline AVT-FG-V4 & 102 & 13.3 & 88 & 26 & 163 & 144 & 89 & 138 & 27 & 59.7 \\
\hline AVT-FG-V5 & 102 & 13.0 & 91 & 26 & 189 & 174 & 93 & 136 & 25 & 70.7 \\
\hline AVT-FG-V6 & 101 & 11.9 & 90 & 27 & 124 & 109 & 88 & 136 & 24 & 69.1 \\
\hline
\end{tabular}

The trait spikelet fertility is an important component which is directly related with yield. In this study most of the high yielding genotypes have spikelet fertility in range of $70-80 \%$. The highest spikelet fertility is observed in check variety SKUA-420 (94\%) and lowest for AVT.IM(H)2712 (32\%). It is also found that highest spikelet fertility was found for genotype which matures early as compared to late maturing genotypes. Akhi et al., (2016) reported that spikelet fertility status (\%) do have high positive direct effect with grain yield.

Days to maturity showed presence of significant variation among the genotypes studied and early maturing genotypes are more preferred because their high yield and earliness is suitable criterion for selection of improved varieties and early maturing genotypes like AVT-FG-V1, AVT-FG-V2, AVT-FG-V4, AVT-FG-V5, AVT-FG-V6, AVTFG-V8, AVT-1-V3, IVT-BT-3010, PVT-V1, IVT.1M(H)-2817,AVT-I(E)2511, IVT.IE(H) 2816, IURON-20, IURON-8, IURON-10, IRTON-23 and IRTON-25 with an average mean of 135 days were identified as desirable types from the point of yield, similar results were reported by Abdallah et al., (2010) (Table 2).

In this study most of the high yielding varieties showed spectrum of variation for test weight and most of the high yielding genotypes have 1000 seed weight in the range of $20-27 \mathrm{~g}$. Minimum 1000 grain weight of $20 \mathrm{~g}$ was recorded by IVT.IM(H)2817, while maximum $33 \mathrm{~g}$ were recorded by IIRON-5. This in contrast with Tahir et al., (2003) who reported positive correlation between 1000 grain weight and grain yield of rice.

Grain yield in rice is complex trait and highly dependent on other agro-morphological characters. Grain yield is the ultimate manifestation of a plants ability to survive, grown and produce more yields under different climatic conditions. Grain yield of fine and semi fine rice under temperate conditions of Kashmir differed significantly among rice genotypes (Table 1) in this study yield data revealed that good genotype variability exhibited among the genotype with a range of 15.1 (AVT.IM 2701) to 81.6 (IRTON-25). Among the rice genotypes evaluated, the highest seed yield per hater was recorded in genotypes viz. IRTON-25, AVTFG-V1, AVT-FG-V2, AVT-FG-V5, AVT-FGV6, AVT-FG-V8, IVT.IE(H)2606 and PVTV1. Other entries like AVT-FG-V4, IURON20, IURON-8, IURON-10, IRTON-23, IRTON-25 and AVT-1-V3 registered moderate yield and lowest yield was observed with AVT.IM(H) 2704, AVT.IM(H)2712, IVT-BT3022, IVT-BT-3020,IVT-BT-3024, GS-394, GS-388,GS-389,GS-390, GS-394,GS-393, $\operatorname{AVT.IM}(\mathrm{H})$ 2816and IIRON-5. The checks, SKUA-494, SKUA-420, Pusa Sugand-3 and Pusa Basmati-1509 gave 69.7, 72.4, 28.6 and $28.0 \mathrm{q} / \mathrm{ha}$ (Table 2). Such variation among rice 
genotypes for yield was also reported by Silva (2009), Ashrafuzzaman et al., (2009) and Hossain et al., (2005). Vanisree et al., (2013) studied association analysis of fifty genotypes comprising both basmati and aromatic short grain types and revealed that grain yield was significantly associated with harvest index, plant height, days to $50 \%$ flowering, panicle length, number of grains per panicle and filled grain per panicle.

Yield and yield attributing traits of basmati rice type were evaluated by a number of workers like Zahid et al., (2006), Tayeng and Singh (2006), Shobha et al., (2006) and it was reported that that the number of tillers per plant, grains per panicle and 1000-grain weight, fertile spikelets followed by plant height contributed maximum direct effects on yield. Also Sarawgi et al., (2015) reported that the leaf length, leaf width, days to $50 \%$ flowering, effective tiller, plant height, panicle length and days to maturity had positive direct effect on grain yield per plant.

Finally among 56 rice genotypes including checks in augmented block design, 19 genotypes exhibited higher yield and its attributing characters in comparison with four checks in temperate conditions of Kashmir valley.

It is obvious from the results that the grain yield and its attributing characters exhibit significant variation among the rice genotypes studied. Also the agro-morphological traits studied have direct positive effect on grain yield. So these parameters may be given prime importance for the direct improvement of grain yield in this group of fine and semi fine rice grain genotypes studied in temperate conditions of Kashmir.

\section{References}

AIREA 2015. All India Rice Exporters Association "Export Statistics of
Basmati Rice, Directorate of Economics \& Statistics, p. 58.

Akhtar, M., Saleem, A.M and Haider, Z. 2015. PK 386: A NEW HIGH YIELDING, EARLY MATURING, LONG GRAIN RICE (ORYZA SATIVA L.) VARIETY. Journal of Agriculture Research. 53(3):321-330.

Aide, M., D. Beighley, 2006.Hyperspectral reflectance monitoring of rice varieties grown under different nitrogen regimes. Transactions of Missouri Academy of Science, 40: 6-11.

Ashrafuzzaman, M., Islam, M.R., Ismail, M.R., Shahidullah, S.M. and Hanafi, M.M. 2009. Evaluation of six aromatic rice varieties for yield and yield contributing characters. Int. J. Agric. Biol. 11:616-620.

Akhi, A. H., Miah, M. A. K., Ivy N. A., Islam, A.and Islam, M. Z.2016. Association of yield and yield related traits in Aromatic rice (Oryza sativa 1.). Bangladesh J. Agril. Res. 41(3): 387396.

Abdallah, A.A., Ammar, M.H. and Badawi, A.T. 2010. Screening rice genotypes for drought resistance in Egypt. Journal of Plant Breeding and Crop Science. 2(7):205-215. 285

Ashrafuzzaman, M., Islam, M.R., Ismail, M.R., Shahidullah, S.M. and Hanafi, M.M. 2009. Evaluation of six aromatic rice varieties for yield and yield contributing characters. Int. J. Agric. Biol. 11:616-620.

BEDF.2016. Basmati Export Development Foundation. Basmati Acreage and yield estimation in Punjab Haryana, Delhi, Uttrakhand, Himachal Pradesh and parts of Jammu \& Kashmir. Report volume-3. AgriNet solutions. p.2.

Basanti, B., Deepika, C., JAIN, R.K. and Sunita. J. 2018. Agronomic characterization of rice genotypes and 
its relations with yield trait. International Journal of Genetics. 10(2): 349-353.

Garris, A.J., Tai, T. H., Coburn, J., Kresovich S. and McCouch, S.R. 2005. Genetic structure and diversity in Oryza sativa L. Genetics.169(3): 1631-1638.

Hughes, A.R., Inouye, B.D., Johnson, M.T.J., Underwood N. and Vellend, M. 2008. Ecological consequences of genetic diversity. Ecology Letters. 11(6): 609623.

Hossain, M.F., Bhuiya, M.S.U. and Ahmed, M. 2005. Morphological and agronomic attributes of some local and modern aromatic rice varieties of Bangladesh. Asian J. Plant Sci. 4: 664-666.

Mannan, M.A., Bhuiya, M.S.U., Hossain, S.M.A. and Akhand, M.I.M. 2009. Study on phenology and yielding ability of basmati fine rice genotypes as influenced by planting date in aman season. Bangladesh J. Agril. Res. 34(3): 373-384.

Naseem, I., Khan, A.S. and Akhter, M. 2014. Correlation and path coefficient studies of some yield related traits in rice (Oryza sativa L.). Journal of Scientific and Research Publications 4(4): 1-5.

Ndour, D., Diouf, D., Bimpong, I.K., Sow, A., Kanfany, G. and Manneh,B.2016. Agro-Morphological Evaluation of Rice (Oryza sativa L.) for Seasonal Adaptation in the Sahelian Environment. Agronomy. 16(8):1-19.

Ranawake1. A. L.., Amarasinghe, U. G. S., M. J. Hewage. and N. G. J. Pradeepika. 2014. Effect of Days to Flowering on Plant Height and Yield of Rice (Oryza sativa L.).International Journal of Plant \& Soil Science. 3(9): 1143-1152.

Roy, S., Banerjee, A., Senapati, B.K. and Sarkar G. 2012.Comparative analysis of agro-morphology, grain quality and aroma traits of traditional and Basmati type genotypes of rice (Oryza sativa L.). Plant Breeding 131(4): 486-492.

Ranawake, A.L., Amarasingha, U.G.S. and Dahanayake, N. 2013. Agronomic characters of some traditional rice (Oryza sativa L.) cultivars in Sri Lanka. J.Univ.Ruhuna. 1(1):3-9.

Sedeghi, S.M. 2011. Hertibility, phenotypic correlation and path correlation studies for some Agronomic characters in landrace rice varieties. World Applied Science Journal. 13(5):1229-1233

Sajid, M., Khan, A.S., Khurshid, H., Javed, I., Muhammad, A., Saleem, N. et al., 2015. Characterization of Rice (Oryza sativa L.) Germplasm through Various Agro-Morphological Traits. Scientia agriculture 8(6):287-293.

Silva, N.P.S. 2009. Genetic variability of important traits and their association with grain yield in rice. Annals of the Sri Lanka. 11:23-32.

Sarawagi, A.K., Ojha, G.C., Koshta, N. and Pachauri, A. 2015. Genetic divergence and association study for grain yield in rice (Oryza sativa L.) germplasm accessions. The Ecoscan 9(1\&2): 217223.

Shobha Rani., N., Pandey, N.K., Prasad, G.S.V and Sudharshan, I.2006.Historical significance, grain quality features and precision breeding for improvement of export quality basmati varieties in India. Indian Journal of Crop Science. 1(1-2): 29-41.

Thippeswamy, S., Chandramohan, Y., Srinivas, B. andPadmaja, D. 2016. Selection of diverse parental lines for heterotic hybrid development in rice (Oryza sativa L.). SABRAO J. of Breed, and Genet.48(3): 285-294.

Tahir M., D. Wadan and A. Zada. 2002. Genetic Variability of Different Plant Yield Characters in Rice. Sarhad J. Agric. 18(2).

Tayeng, $\mathrm{T}$ and Singh, M.R.K. 2006. 
Correlation and path analysis in some early rice genotypes under pre kharif conditions of Manipur Valley. Environment and Ecology 24 (2): 265267.

Uddin, M.J., Hasan, M.M., Ahmed, S. and Hasan, M.M.2010. Effect of spacing on morpho-physiological response of different $T$. aman rice cultivars under coastal high land ecosystem. Indian J.Agric. Res. 44: 251-258.

Vanisree, S., Anjali, K., DamodarRaju, Ch., SurenderRaju, Ch. And Sreedhar, M. 2013. Variability, heritability and association analysis in scented rice. Journal of Biological and Scientific Opinion. 1(4): 347-352.

Verma, D.K., Mohan, M., Yadav, V.K., Asthir, B., Soni, S.K. 2012. Inquisition of some physico-chemical characteristics of newly evolved basmati rice. Environment and Ecoplanting. 30: 114-117.

Vijay Kumar, 2015. Genetic diversity and character association studies for some economic traits in rice (Oryza sativa L.). An Intl. Quarterly J. of Life Sci. 10(2): 899-904.

Wattoo, J.I., Khan, A.S., Muhammad, Z.A., Naeem, M., Ullah, M.A. and Hussain, N. 2010. Study of correlation among yield related traits and path coefficient analysis in rice (Oryza sativa L.). African Journal of Biotechnology 9 (46):7853-7856.

Zahid, M.A., Akhtar, M., Sabir, M., Manzoor, $\mathrm{Z}$ and Awan, T.H. 2006. Correlation and path analysis studies of yield and economic traits in Basmati rice. Asian Journal of Plant Sciences 5: 643-645.

\section{How to cite this article:}

Uzma Mehraj, F.A. Sheikh, S. Najeeb, Mushtaq Ahmad, A.B. Shikari, Shabir H. Wani, M.A. Ahangar, M.A. Khan and Bhat, M.A. 2019. Evaluation and Selection of Fine and Semi Fine Rice Grain (Oryza sativa L.) Genotypes for Agro-Morphological Traits under Augmented Block Design in Temperate Conditions of Kashmir Valley. Int.J.Curr.Microbiol.App.Sci. 8(11): 1522-1530. doi: https://doi.org/10.20546/ijcmas.2019.811.177 